\title{
Comparison of metabolic, hematological, and peripheral blood leukocyte cytokine profiles of dairy cows and heifers during the periparturient period
}

\author{
N. N. Jonsson, ${ }^{* 1}$ M. R. S. Fortes, $†$ E. K. Piper,† D. M. Vankan, † J. Prada J. de Cisneros, $\ddagger$ and T. Wittek§ \\ *University of Glasgow, School of Veterinary Medicine, Scottish Centre for Production Animal Health and Food Safety, Glasgow G61 1QH, \\ United Kingdom \\ †The University of Queensland, School of Veterinary Science, Brisbane, Australia 4072 \\ fUniversity of Glasgow, Institute of Infection, Immunity and Inflammation, Glasgow G61 1QH, United Kingdom \\ §Veterinärmedizinische Universität Wien, Klinik für Wiederkäuer, A 1210 Wien, Austria
}

\section{ABSTRACT}

The periparturient period presents major physiological challenges for the dairy cow. It is a period that is affected by metabolic stressors, major changes in endocrine status, and altered immune function, which together result in an increased risk of disease. Immunological, hematological, and metabolic profiles from the periparturient period of heifers (primipara) were compared with those of cows (pluripara) to test the hypothesis that at the time of calving they have qualitatively different peripheral blood profiles. Blood samples were collected from 22 Holstein-Friesian animals on 3 occasions: approximately 2 wk before calving, within $24 \mathrm{~h}$ after calving, and approximately $2 \mathrm{wk}$ after calving. Quantitative PCR was used to measure the expression of a selected set of cytokines and receptors by peripheral blood leukocytes. Additional analyses included hemoglobin concentration, red cell, platelet and white cell counts (total and differentiated), and clinical diagnostic biochemical profiles. Total leukocyte counts, neutrophils, and lymphocytes were higher in heifers than cows before calving and within $24 \mathrm{~h}$ after calving. Alkaline phosphatase was consistently higher in heifers than cows and several significant differences were observed between the 2 groups with regards to cytokine and cytokine-receptor mRNA expression. The results warrant further investigation from the perspective of identifying risk factors for metabolic and parturient disease in dairy cattle.

Key words: cytokine, parturition, bovine, hypocalcemia

\section{INTRODUCTION}

The transition period from 3 wk before to 3 wk after calving presents enormous physiological challenges for

Received September 17, 2012

Accepted January 2, 2013.

${ }^{1}$ Corresponding author: nicholas.jonsson@glasgow.ac.uk the dairy cow. It is a period that is affected by metabolic stressors, major changes in endocrine status, and altered immune function, which together result in an increased risk of diseases including hypocalcaemia, ketosis, hepatic lipidosis, laminitis, abomasal displacement, mastitis, retained placenta, and metritis (Ingvartsen et al., 2003; Mulligan and Doherty, 2008). Considerable research has been conducted into the changes in immune function that occur around the time of calving, mostly from the perspective that immuno-suppression in this period might increase susceptibility to periparturient infectious diseases (Goff and Horst, 1997; Karcher et al., 2008). In part, this has been attributed to elevated cortisol in the prepartum period, with a concomitant reduction in density of glucocorticoid receptors on neutrophil cell membranes (Preisler et al., 2000), but also to changes in concentrations of circulating sex hormones during this period (Miyaura and Iwata, 2002; Maret et al., 2003; Radcliff et al., 2003).

Another focal point for researchers has been to identify the role of immunity in the maintenance and termination of pregnancy. It has been shown that bovine trophoblast cells express major histocompatibility complex antigens beginning at 6 mo of pregnancy, resulting in inflammatory processes which are likely to be important for placental maturation and release in cattle (Davies et al., 2004). van Engelen et al. (2009) also demonstrated that uterine cervical maturation in cows during the last week of gestation is an inflammatory process as a result of fetal antigen presentation. It is also recognized that an increase in proinflammatory cytokine production by peripheral blood mononuclear cells exists in the uterus during and after parturition in cattle (Ametaj et al., 2003; Singh et al., 2008). Given these findings, it would be expected that the immunological response of primiparous heifers would differ from that of older cows that had previously been exposed to foreign fetal antigens.

The central role of cytokines in bone turnover is accepted in human medicine; in particular tumor necrosis factor $\alpha(\mathbf{T N F}-\alpha)$ and IL-1 have been shown to modu- 
late the expression of receptor activator of nuclear factor $\kappa-\mathrm{B}$ (RANK), its ligand (RANKL), and osteoprotegerin (Datta et al., 2008; Leibbrandt and Penninger, 2008) in mice, but little attention has been paid to the subject in livestock. We have previously speculated that variations in cytokine production in tissue and blood might also influence calcium metabolism during the parturient period, with potential implications for the occurrence of parturient paresis (milk fever or clinical hypocalcemia), which is very rare in first-calving cattle and increases in incidence with parity (Gray et al., 2007).

We subsequently hypothesized that detectable differences exist in the patterns of cytokine responses and other immune effectors in primiparous heifers compared with multiparous cows around the time of calving. This paper describes a pilot study to test our hypothesis, reporting transition period cytokine, as well as the hematological and biochemical, profiles of a small number of clinically normal heifers and cows using a selection of markers of innate and adaptive immunity.

\section{MATERIALS AND METHODS}

\section{Animals}

Twenty-two female Holstein-Friesian animals (12 cows that had calved at least once before and 10 heifers that had not previously calved) were used for this trial. Cows were born between September 1997 and August 2004, and heifers were born between October 2005 and February 2006. Clinical signs of disease were recorded and samples collected from cattle that were clinically abnormal were excluded from analysis. All animals in the study were managed under the same conditions in the same paddock and supplied with the same ration, which varied slightly over time according to pasture availability. Before calving, all animals grazed only pasture, which consisted of tropical grasses, primarily Rhodes grass (Chloris gayana), kikuyu (Pennisetum clandestinum), and green panic (Panicum maximum var. trichoglume). After calving, all animals received a lactating cow diet that included maize silage in addition to free access to pasture. Cows and heifers belonged to the University of Queensland (UQ) dairy herd and the study was conducted with the approval of the UQ Animal Ethics Committee. Animals were selected for the trial according to the expected calving date, calculated from artificial insemination records.

\section{Blood Collection}

Blood samples were obtained from each animal at 3 time points: as close as possible to 2 wk before calving, at calving, and as close as possible to 2 wk postcalving. Precalving samples were collected between 32 and $5 \mathrm{~d}$ before calving. Calving samples were obtained within $24 \mathrm{~h}$ after parturition. Postcalving sampling occurred between 11 and $18 \mathrm{~d}$ after parturition. Blood was collected via jugular venipuncture into Vacuette blood tubes (Greiner Bio-One, Stonehouse, UK); $2 \times$ EDTA, $2 \times$ Z-clot activator, and $1 \times$ fluoride-oxalate blood tubes.

\section{Hematological and Biochemical Analyses}

Blood samples collected into EDTA were used for hematological analysis performed at UQ School of Veterinary Science Diagnostic Services Laboratory. Hematological analyses were performed using a Coulter cell counter ( $\mathrm{A}^{\mathrm{c}}$.T diff, Beckman Coulter, Brea, CA) and included analysis of hemoglobin, red cell count, platelet count, packed cell volume, and total white cell count (WCC). Differentiated WCC (neutrophils, lymphocytes, eosinophils, basophils, monocytes, band neutrophils) were performed manually using standard slide preparations stained with Wright's stain.

Blood samples collected into Fl-oxalate tubes were submitted for biochemical analysis using an Olympus AU400 Clinical Chemistry Analyzer (Beckman Coulter) for plasma concentrations or enzyme activities of calcium, sodium, magnesium, potassium, alkaline phosphatase (ALP), albumin, creatine phosphokinase, phosphate, chloride, aspartate aminotransferase, total protein, globulin, anion gap, bicarbonate, $\gamma$-glutamyl transpeptidase, triglycerides, total bilirubin, urea, glucose, and lactate dehydrogenase.

\section{Isolation of RNA from White Blood Cells}

Five milliliters of blood collected in EDTA was added to $45 \mathrm{~mL}$ of red blood cell lysing buffer $\left(0.19 \mathrm{M} \mathrm{NH}_{4} \mathrm{Cl}_{2}\right.$, $0.01 M$ Tris) and allowed to stand at room temperature for $10 \mathrm{~min}$. Samples were then centrifuged at 250 $\times g$ for $10 \mathrm{~min}$ and the supernatant was removed. The cell pellet was resuspended in $1.5 \mathrm{~mL}$ of Trizol reagent (Life Technologies, Mulgrave, Australia) and samples were stored at $-80^{\circ} \mathrm{C}$ before RNA extraction. Extraction of total RNA was carried out according to the manufacturer's instructions for Trizol reagent (Life Technologies). The RNA pellet was resuspended in $30 \mu \mathrm{L}$ of RNase-free water, treated with $0.75 \mu \mathrm{L}$ of Turbo DNase (Ambion, Austin, TX) according to the manufacturer's instructions and re-extracted with phenol-chloroform ( $\mathrm{pH}$ 4.7). The RNA was resuspended in $50 \mu \mathrm{L}$ of RNase-free water and stored at $-80^{\circ} \mathrm{C}$ until required. 


\section{Quantitative PCR}

Complementary DNA synthesis was carried out using $2 \mu \mathrm{g}$ of total RNA. The complimentary strand was primed using OligoDT primers (Invitrogen) and cDNA synthesis was performed using a Superscript III kit (Invitrogen) according to the manufacturer's instructions.

Each quantitative PCR reaction contained $20 \mathrm{ng}$ of cDNA, SensiMixPlus SYBR Master Mix (Quantace, Sydney, Australia), $0.125 \mathrm{nmol}$ of forward primer, and $0.125 \mathrm{nmol}$ of reverse primer. Primer sequences are listed in Table 1. Some primer sequences have been previously published (Coussens et al., 2004; Strandberg et al., 2005), whereas some were designed using the Primer3 software (available at http://frodo.wi.mit. $\mathrm{edu} /$ ). Standard curves were generated for each primer set to obtain the amplification efficiency and the specificity of the primers was checked using melting curve analysis. Quantitative PCR for each sample was performed in duplicate using standard cycling conditions on a RotorGene 6000 (Qiagen, Melbourne, Australia). The mean of the cycle threshold values were calculated for each gene analyzed for each biological sample and normalized against 2 internal controls: GAPDH and acidic ribosomal protein large P0. Normalization was performed using the QGene software (available at http://www.qgene.org/). Mean normalized expression values were employed for statistical analysis.

\section{Data and Statistical Analysis}

Each measured parameter (cellular, biochemical, and gene expression) was first tested for normality using the Kolmogorov-Smirnov test. Because several parameters were not normally distributed, the data are presented as median, first quartile, and third quartile. Data were transformed, when necessary, using either square root or natural logarithmic conversions, and were analyzed only when not different from a normal distribution $(P$ $>0.10)$. All of the cytokines required natural logarithmic transformation except TNF- $\alpha$, which was normally distributed. Two variables (IFN- $\gamma$ and CD19) were not able to be effectively transformed to fit a normal distribution. The nonparametric Mann-Whitney U test was performed within each time point (precalving, calving, and postcalving), for the fixed effect of age group (cow or heifer), and for each of the characteristics that was not normally distributed. Transformed and normally distributed data were analyzed using Student's twotailed $t$-test. The software package OpenStat (http:// openstat.en.softonic.com/) was used for all statistical analyses.

Another approach to identifying patterns of variation among time points and among groups of animals was

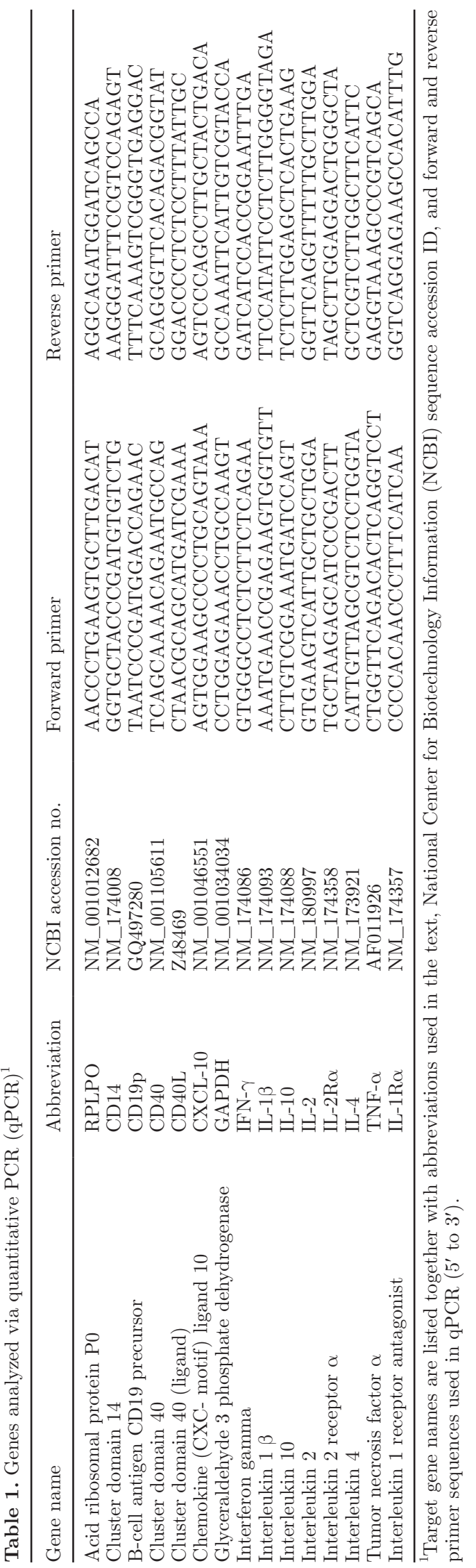

Journal of Dairy Science Vol. 96 No. 4, 2013 
to graphically compare time-series differences between standardized observations on cows and heifers. Because we were interested in proportional changes of expression of genes or concentrations of cells or biochemical measures over time, all values were standardized by dividing each individual observation for a variable by the median value for that variable for all observations. The R software (http://www.r-project.org/) was applied to these standardized values. The mean and standard deviations of the standardized observations were calculated for the cows at each time point (precalving, calving, and postcalving); the values for the heifers were then plotted against them at each time point to highlight variables of heifers with mean standardized values that fell outside the $95 \%$ CI for observations on cows.

\section{RESULTS}

Hematological measurements are listed in Table 2, biochemistry in Table 3 and gene expression results are shown in Figures 1 and 2 and 3. Median days before calving for heifers was 17 (range $5-32$ ), which was not different from cows (median 20; range 8-30; $P=0.43)$. Precalving results show that the WCC was higher in heifers than in cows $(P=0.004)$, as were lymphocytes $(P<0.001)$ and neutrophils $(P=0.025)$. Among the biochemical measurements, chloride $(P=$ $0.027)$ and glucose $(P=0.013)$ were lower in cows; globulin concentration was higher in cows $(P=0.044)$. Before parturition the only gene that was differentially expressed between the 2 groups was chemokine (CXCmotif) ligand 10, a proinflammatory chemokine, which was higher in heifers than in cows $(P=0.038)$.

The timing of the sample collection on the day of calving was similar in cows and heifers, the majority being collected on the morning after a night-time calving in both groups. Total WCC was higher in heifers $(P=$ $0.028)$, with neutrophils $(P=0.043)$ and lymphocytes $(P=0.049)$, specifically, being higher in heifers than cows. Of the biochemical parameters, creatine phosphokinase activity was higher in heifers $(P=0.045)$ at calving. The expression of IL-1 $\beta$ was significantly higher in heifers $(P=0.008)$, the chemokine CD 40 (ligand) was higher in heifers $(P=0.047)$ and its receptor, CD 40, tended to be higher in heifers $(P=0.077)$, as did CD 19 $(P=0.092)$. Total plasma protein concentration $(P=$ $0.054)$ tended to be lower in heifers as did total globulin $(P=0.098)$. Levels of IFN- $\gamma$ tended to be higher in cows $(P=0.067)$.

The 2 -wk postcalving sample collection time was similar in cows (median 15; range 11-16 d) and heifers (median 15; range 13-18 d; $P=0.95$ ). Eosinophil counts were significantly higher in cows $(P=0.006)$.

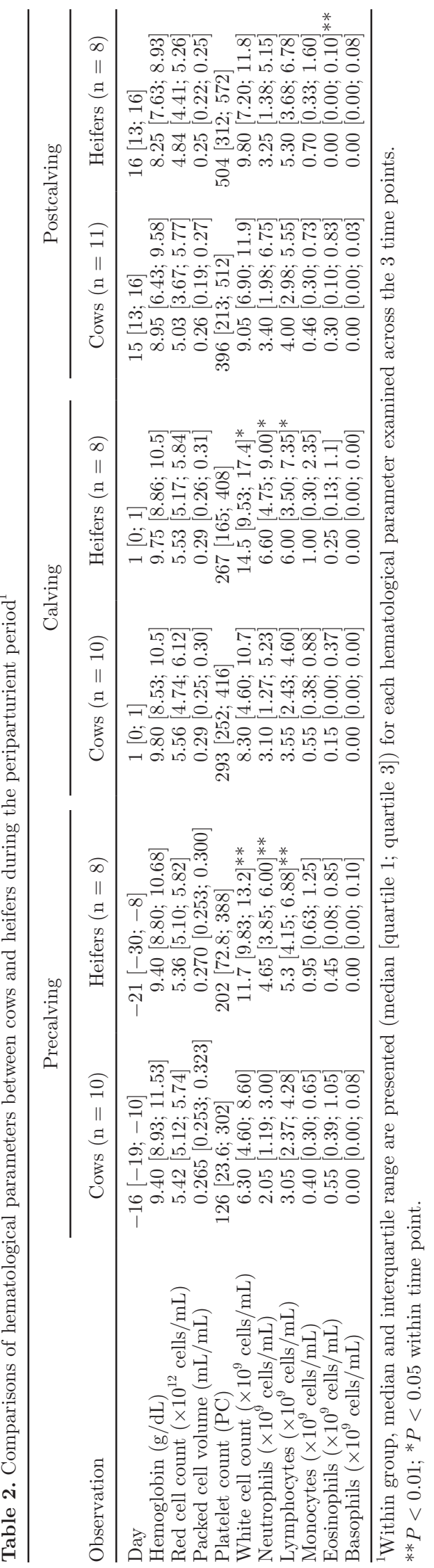


Table 3. Comparisons of clinical biochemical parameters between cows and heifers during the periparturient period $^{1}$

\begin{tabular}{|c|c|c|c|c|c|c|}
\hline \multirow[b]{2}{*}{ Parameter $^{2}$} & \multicolumn{2}{|c|}{ Precalving } & \multicolumn{2}{|c|}{ Calving } & \multicolumn{2}{|c|}{ Postcalving } \\
\hline & Cows $(\mathrm{n}=10)$ & Heifers $(\mathrm{n}=12)$ & Cows $(\mathrm{n}=10)$ & Heifers $(\mathrm{n}=10)$ & Cows $(\mathrm{n}=11)$ & Heifers $(\mathrm{n}=9)$ \\
\hline Total protein $(\mathrm{g} / \mathrm{L})$ & $77.5[71.0 ; 78.25]$ & $67.7[65.3 ; 74.0]$ & $70.9[66.2 ; 72.7]$ & $66.0[64.0 ; 68.0]$ & $76.5[70.8 ; 80.8]$ & $75.0[66.0 ; 84.8]$ \\
\hline Albumin $(\mathrm{g} / \mathrm{L})$ & $30.5[28.8 ; 31.0]$ & $30.6[29.9 ; 33.3]$ & $31.0[30.0 ; 33.3]$ & $31.1[30.0 ; 32.8]$ & $30.7[25.8 ; 33.0]$ & $30.8[26.0 ; 33.0]$ \\
\hline Globulin $(\mathrm{g} / \mathrm{L})$ & $47.5[40.8 ; 49.5]$ & $38.0[35.1 ; 43.4]^{*}$ & $39.0[34.3 ; 42.4]$ & $34.1[33.7 ; 35.0]$ & $47.5[41.0 ; 48.5]$ & $43.6[38.3 ; 48.8]$ \\
\hline Calcium (mmol/L) & $2.19[2.07 ; 2.23]$ & $2.09[2.03 ; 2.16]$ & $2.02[1.80 ; 2.16]$ & $1.99[1.92 ; 2.10]$ & $2.05[1.97 ; 2.23]$ & $2.09[2.01 ; 2.25]$ \\
\hline Sodium $(\mathrm{mmol} / \mathrm{L})$ & $140[137 ; 142]$ & $142[141 ; 145]$ & $145[141 ; 147]$ & $145[140 ; 150]$ & $138[137 ; 141]$ & $140[136 ; 141]$ \\
\hline Magnesium $(\mathrm{mmol} / \mathrm{L})$ & $0.88[0.85 ; 0.91]$ & $0.91[0.83 ; 0.96]$ & $0.85[0.77 ; 0.93]$ & $0.96[0.86 ; 1.00]$ & $0.87[0.80 ; 0.91]$ & $0.87[0.83 ; 0.90]$ \\
\hline Phosphate $(\mathrm{mmol} / \mathrm{L})$ & $1.85[1.39 ; 2.42]$ & $2.27[1.82 ; 2.61]$ & $1.85[1.54 ; 2.37]$ & $1.93[1.75 ; 2.03]$ & $1.61[1.31 ; 2.03]$ & $2.09[1.85 ; 2.21]^{*}$ \\
\hline Chloride $(\mathrm{mmol} / \mathrm{L})$ & $103[101 ; 104]$ & $105[103 ; 107]^{*}$ & $105[102 ; 107]$ & $106[99.5 ; 111]$ & $101[98.0 ; 103]$ & $96.5[95.2 ; 99.8]^{*}$ \\
\hline Potassium (mmol/L) & $4.35[4.25 ; 4.65]$ & $4.15[4.03 ; 4.40]$ & $4.50[4.00 ; 4.80]$ & $4.30[4.30 ; 4.78]$ & $4.35[4.18 ; 4.45]$ & $4.40[4.05 ; 4.58]$ \\
\hline $\mathrm{HCO}_{3}(\mathrm{mmol} / \mathrm{L})$ & $20.5[17.5 ; 21]$ & $17.3[15.8 ; 21.9]$ & $22.0[18.4 ; 24.0]$ & $21.5[17.4 ; 25.3]$ & $22.3[18.3 ; 25.3]$ & $24.0[22.5 ; 25.8]$ \\
\hline Anion gap (mmol/L) & $23[21.8 ; 24.9]$ & $23.7[21.9 ; 24.7]$ & $23.1[21.8 ; 24.4]$ & $22.2\lceil 20.6 ; 24.2]$ & $19.7[17.5 ; 22.8]$ & $21.1[19.5 ; 23.0]$ \\
\hline Glucose $(\mathrm{mmol} / \mathrm{L})$ & $3.00[2.58 ; 3.25]$ & $3.35[3.20 ; 3.50]^{*}$ & $3.85[3.65 ; 4.33]$ & $3.65[2.98 ; 4.00]$ & $3.15[2.75 ; 3.38]$ & $3.45[3.00 ; 3.65]$ \\
\hline Urea $(\mathrm{mmol} / \mathrm{L})$ & $5.00[3.55 ; 8.85]$ & $6.90[5.23 ; 8.23]$ & $6.60[5.25 ; 7.60]$ & $5.65[5.13 ; 6.20]$ & $4.25[3.33 ; 5.40]$ & $4.70[4.15 ; 5.48]$ \\
\hline Creatinine $(\mu \mathrm{mol} / \mathrm{L})$ & $111[97.0 ; 122]$ & $101[89.8 ; 112]$ & $102[86.5 ; 112]$ & $97.5[94.8 ; 107]$ & $85.5[70.1 ; 96.9]$ & $83.5[74.9 ; 85.0]$ \\
\hline Cholesterol $(\mathrm{mmol} / \mathrm{L})$ & $2.20[1.98 ; 2.63]$ & $2.15[1.85 ; 2.30]$ & $1.80[1.70 ; 2.03]$ & $1.55[1.43 ; 1.78]$ & $2.50[1.75 ; 3.05]$ & $2.35[1.43 ; 3.05]$ \\
\hline Triglycerides $(\mathrm{mmol} / \mathrm{L})$ & $0.10[0.10 ; 0.10]$ & $0.10[0.10 ; 0.18]$ & $0.05[0.00 ; 0.13]$ & $0.00[0.00 ; 0.08]$ & $0.00[0.00 ; 0.10]$ & $0.10[0.00 ; 0.10]$ \\
\hline Total bilirubin $(\mathrm{mmol} / \mathrm{L})$ & $4.40[3.88 ; 6.30]$ & $4.05[2.88 ; 5.18]$ & $8.55[3.93 ; 15.9]$ & $8.50[6.95 ; 10.7]$ & $6.50[4.00 ; 8.00]$ & $9.25[5.08 ; 15.6]$ \\
\hline $\operatorname{ALP}(\mathrm{U} / \mathrm{L})$ & $38.0[30.8 ; 51.3]$ & $58.00[53.1 ; 76.0]^{*}$ & $54.8[40.0 ; 69.8]$ & $77.5[65.5 ; 96.6]^{*}$ & $32.1[28.3 ; 44.0]$ & $45.5[39.7 ; 52.2]^{*}$ \\
\hline $\mathrm{CK}(\mathrm{U} / \mathrm{L})$ & $78.0[58.5 ; 112]$ & $112[85.3 ; 219]$ & $102[74.0 ; 173]$ & $199[131 ; 411]^{*}$ & $98.2[57.8 ; 111]$ & $101[68.8 ; 140]$ \\
\hline $\operatorname{AST}(\mathrm{U} / \mathrm{L})$ & $60.5[54.8 ; 71.8]$ & $56.0[53.7 ; 66.9]$ & $77.5[73.0 ; 98.0]$ & $75.0[72.0 ; 122]$ & $72.0[56.7 ; 81.3]$ & $59.0[56.6 ; 72.1]$ \\
\hline GGT (U/L) & $13.5[11.1 ; 16.0]$ & $12.5[12.1 ; 13.9]$ & $18.7[11.1 ; 20.9]$ & $17.1[15.1 ; 27.9]$ & $18.4[14.5 ; 21.5]$ & $16.1[12.3 ; 20.0]$ \\
\hline $\mathrm{LDH}(\mathrm{U} / \mathrm{L})$ & $753[743 ; 859]$ & $763[735 ; 936]$ & $876[800 ; 906]$ & $792[705 ; 917]$ & $855[789 ; 940]$ & $705[600 ; 828]$ \\
\hline
\end{tabular}

Postcalving

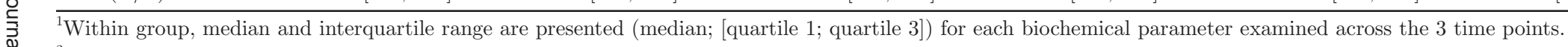

$\cong \quad{ }^{2} \mathrm{HCO}_{3}$ : bicarbonate; ALP: alkaline phosphatase; CK: creatine phosphokinase; AST: aspartate aminotransferase; GGT: $\gamma$-glutamyl transpeptidase; LDH: lactate dehydrogenase

o $* * P<0.01 ; * P<0.05$ within time point. 
IFN $\gamma$

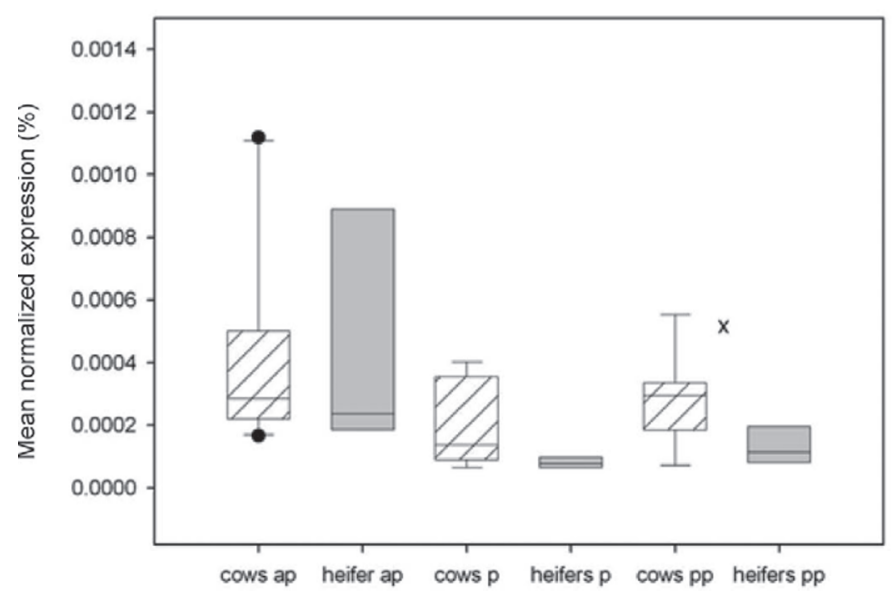

IL-10

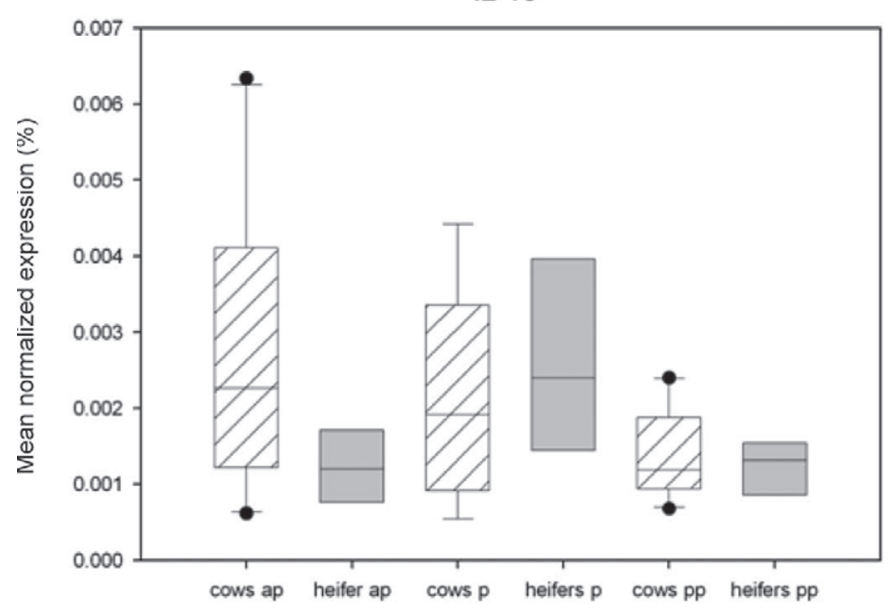

IL1RA

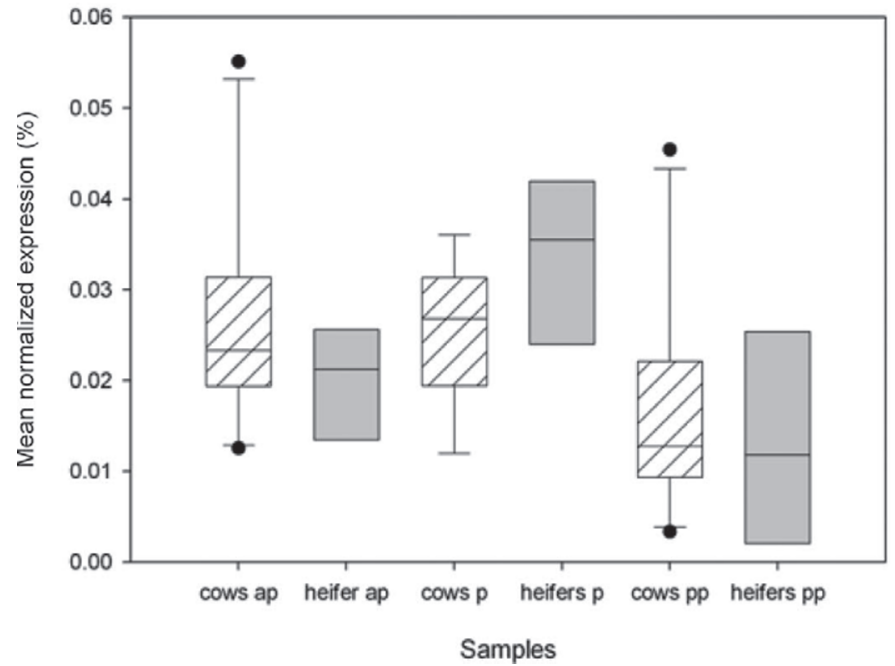

CXCL-10

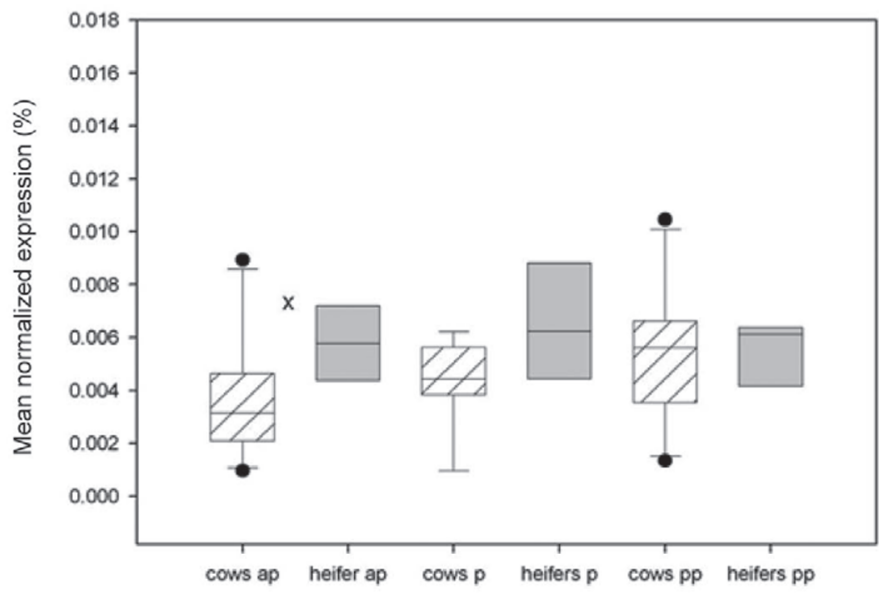

$\mathrm{TNF} \alpha$

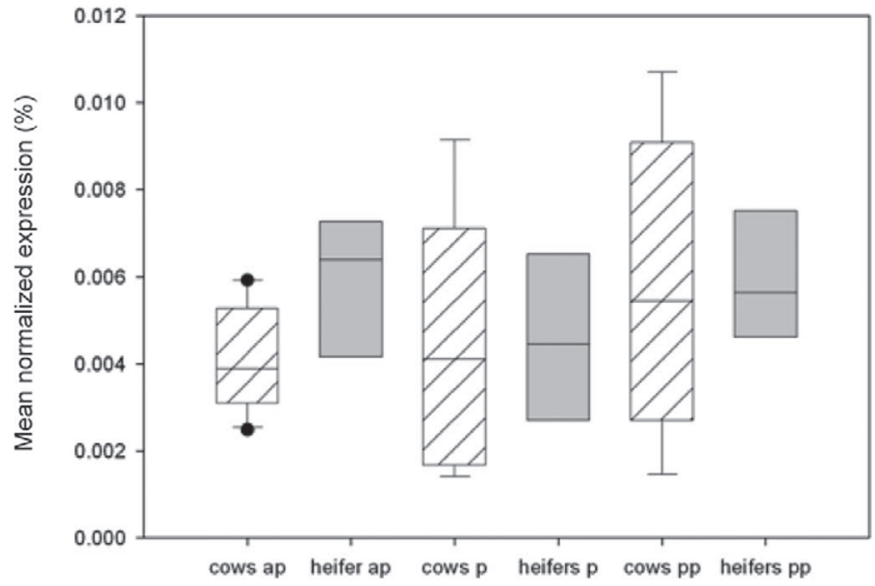

IL1B

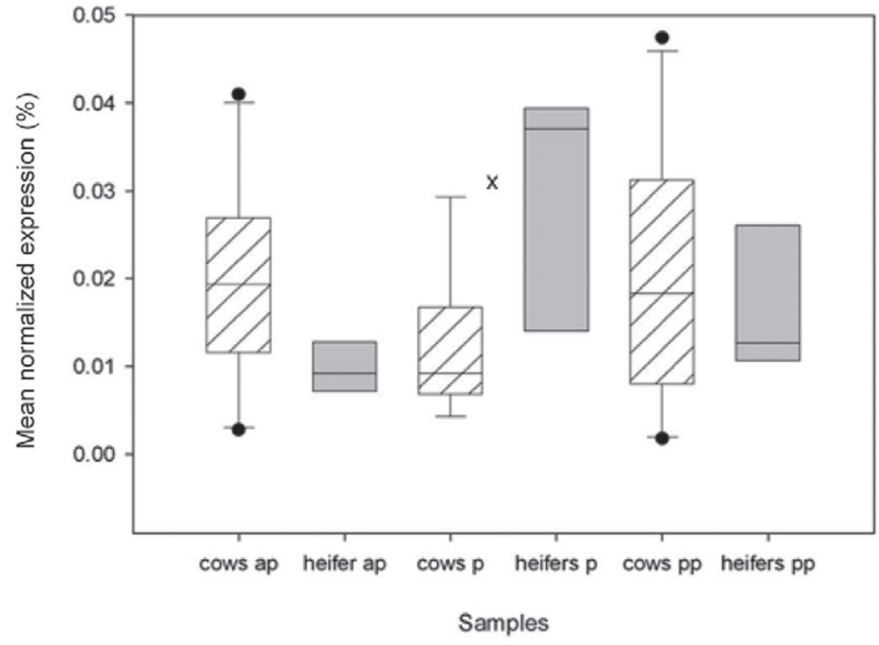

Figure 1. Boxplots of normalized expression of IFN- $\gamma$, chemokine ligand 10 (CXCL-10), IL-10, tumor necrosis factor $\alpha$ (TNF- $\alpha$ ), IL-1 receptor antagonist (IL-1RA), and IL-1 $\beta$ for heifers (gray) and cows (white), precalving (ap), calving (p), and postcalving (pp); ${ }^{\times} P<0.05$. 
IL2

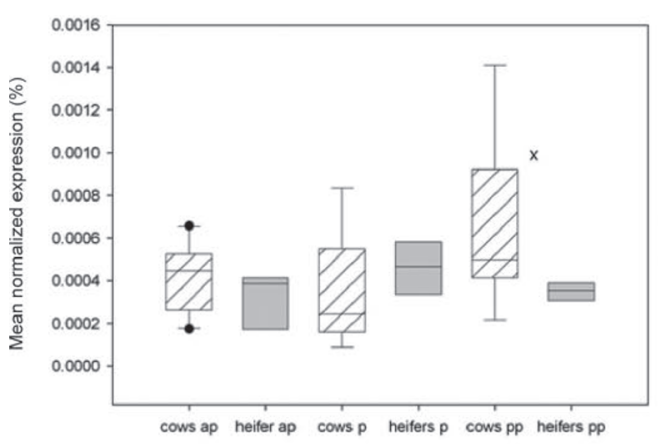

IL4
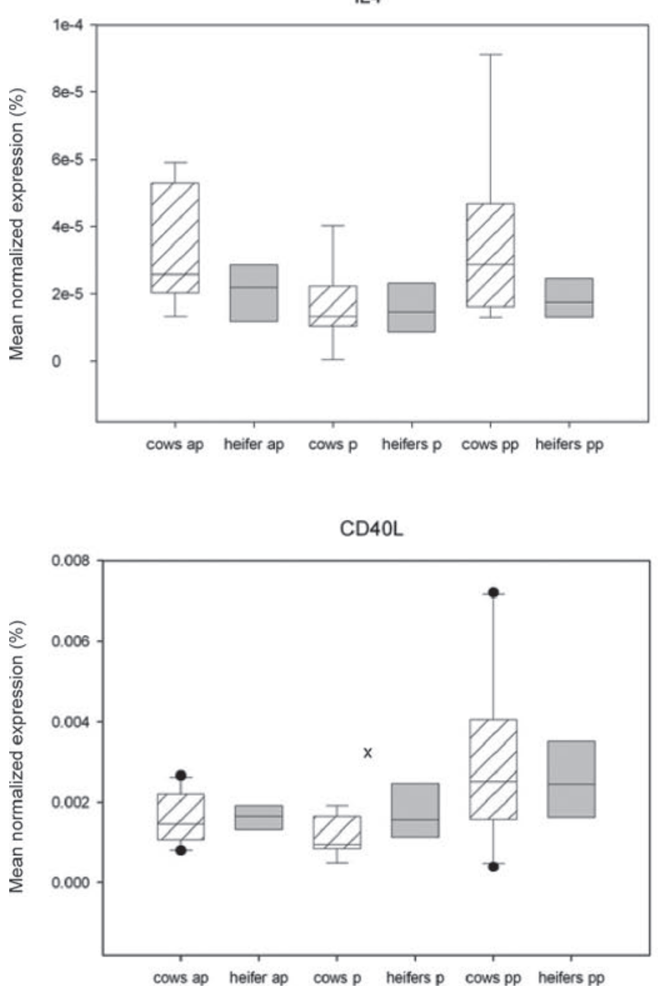

CD40

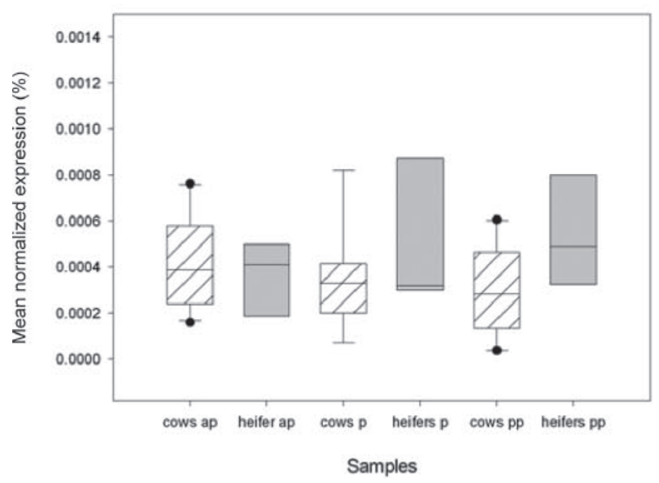

IL2RA

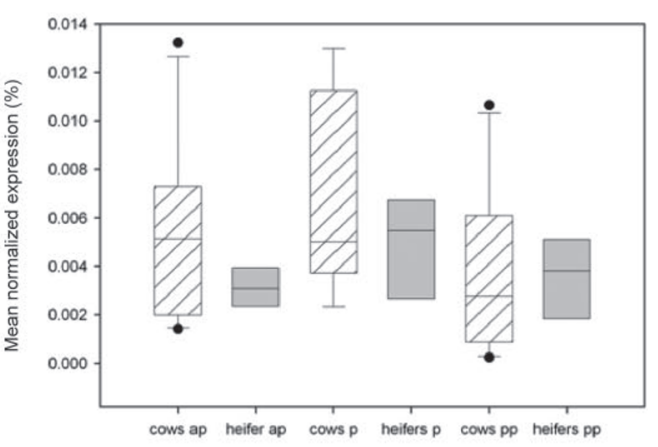

IL6

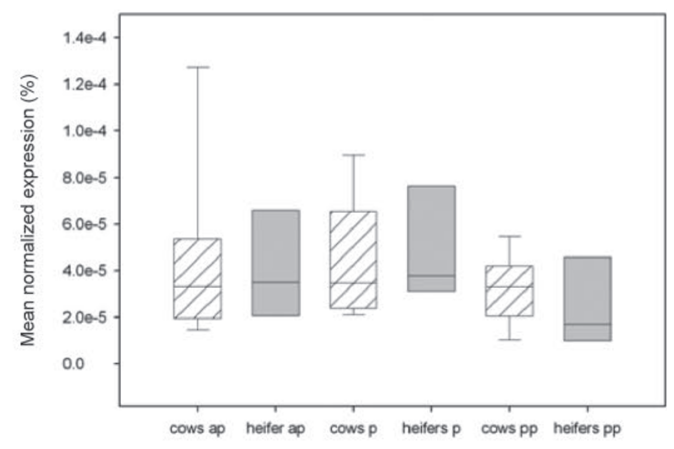

CD19

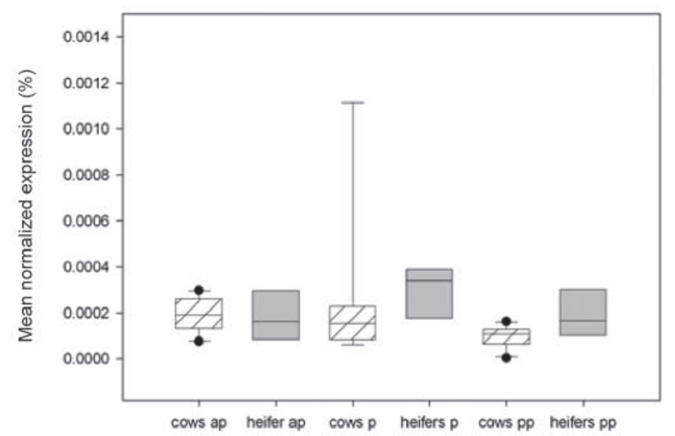

ALP

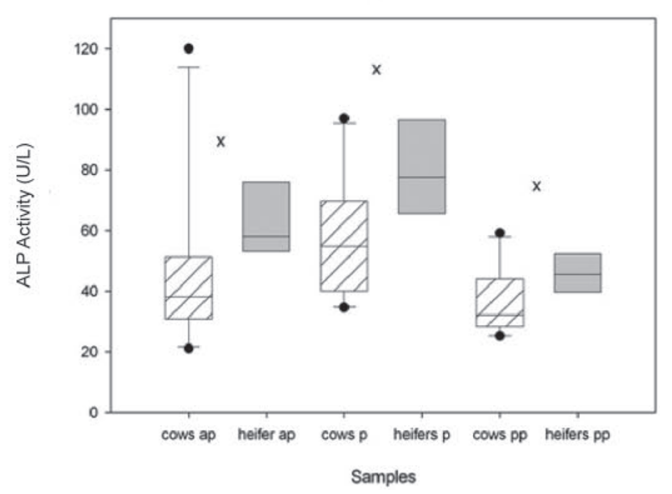

Figure 2. Boxplots of normalized expression of IL-2, IL-2 receptor $\alpha$ (IL-2RA), IL-4, IL-6, cluster domain 40 (ligand; CD40L), cluster domain 40 (CD40), cluster domain 19 (CD19), and alkaline phosphate (ALP) for heifers (gray) and cows (white), precalving (ap), calving (p), and postcalving (pp); ${ }^{\times} P<0.05$. 


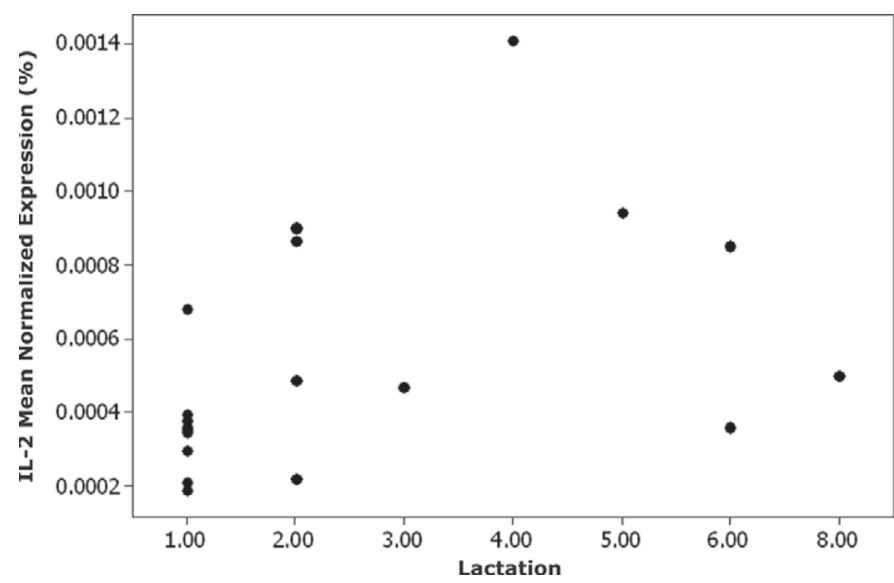

Figure 3. Mean normalized expression of IL-2 at the postcalving time point for each of the heifers (lactation 1) and each of the cows (all other lactations). All but one of the heifer values fall below $0.0004 \%$ (8/9), compared with only 2 of 10 values from pluriparous cows.

Postcalving serum phosphate concentration was higher in heifers than in cows $(P=0.027)$ and chloride concentration was higher in cows than heifers $(P=0.030)$. Gene expression for IL-4 and IL-6 tended to be higher in heifers $(P=0.091$ and $P=0.073$, respectively $)$. The expression of IL-2 $(P=0.012)$ and $\operatorname{IFN}-\gamma(P=0.013)$ was significantly higher in cows 2 wk postpartum.

For some variables, no differences between cows and heifers were observed on any occasion. These variables included hemoglobin, red cell count, packed cell volume, basophils, band neutrophils, albumin, magnesium, aspartate aminotransferase, creatinine, anion gap, bicarbonate, $\gamma$-glutamyl transpeptidase, and CD14. Heifers consistently showed significantly higher levels of ALP over all time points: precalving $(P=0.033)$, calving $(P=0.009)$, and postcalving $(P=0.045)$, as seen in Figure 2.

If it were assumed that the immunological profiles for cows and heifers are the same, after standardizing all the observations the resulting relative values should be similar at each time point (i.e., $95 \%$ of the observations should fall in the interval between 2 standard deviations under and over the mean for each time point). Figure 4 shows the means and 2 standard deviations over and under those mean values in cows for each time point; the small circles are the variables where the mean value for heifers fell outside of the interval. At the precalving time point, only one variable (monocytes count) was observed where the standardized mean value for heifers fell outside the $95 \%$ CI, whereas, at the time of calving, 10 variables outside the $95 \%$ CI (including 8 related to immune function) were observed. At the postcalving time point, 4 variables with mean standardized values in heifers outside the $95 \%$ CI for calves were observed, including eosinophil count and CD 40 (ligand).

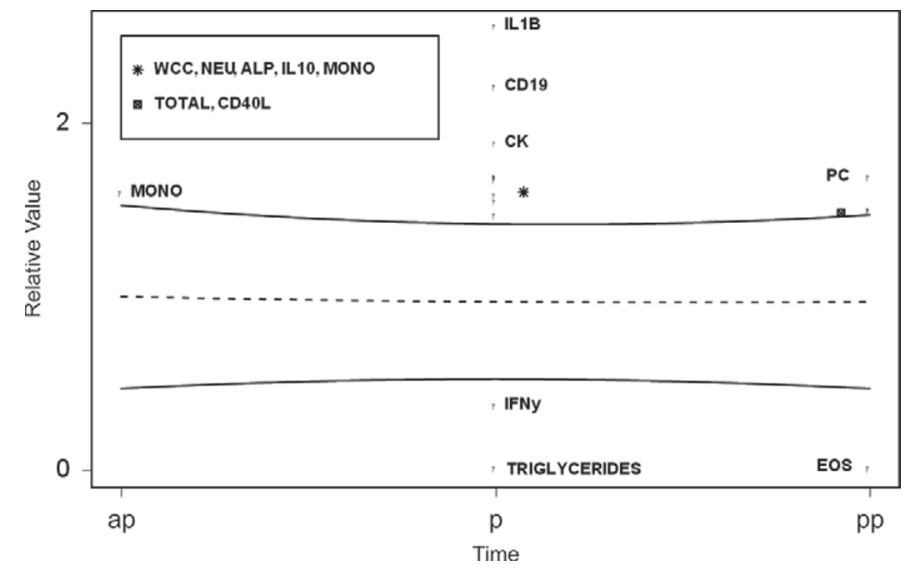

Figure 4. Plot of the mean and $2 \mathrm{SD}$ away from the mean curves for the relative values in cows. Points are the relative values in heifers that are outside of these upper and lower limits. Values in the legend are in ascending order; $\mathrm{x}$-axis time points: precalving (ap), calving (p), and postcalving (pp). WCC $=$ white cell count; NEU = neutrophil count; ALP = alkaline phosphatase; $\mathrm{MONO}=$ monocyte count; CD40L = cluster domain 40 (ligand); CD19= cluster domain 19; CK $=$ creatine phosphokinase; $\mathrm{PC}=$ platelet count $; \mathrm{EOS}=$ eosinophil count.

\section{DISCUSSION}

To our knowledge this is the first comparison of peripheral blood leukocyte cytokine phenotypes of primiparous heifers and pluriparous cows during the periparturient period. This study has demonstrated significant differences between these groups with regards to cytokine expression as well as biochemical and hematological parameters. It seems reasonable to believe that these significant differences have consequences for immune function; however, because this pilot study was a cross-sectional observational study using a limited number of biomarkers of innate and adaptive immunity, it is not possible to make strong inferences about functional consequences of the observed differences.

Bone matrix resorption is carried out by osteoclasts; their differentiation requires the cytokine RANKL, expressed on activated $\mathrm{T}$ cells and osteoblasts, and is inhibited by a competitive binding factor, known as osteoprotegerin, expressed on B cells (Boyce and Xing, 2008; Datta et al., 2008). The T cells have a central role in osteoclast activity, through the expression of RANKL, TNF- $\alpha$, IL-1, IL-6, and IL-17, which are stimulatory, and IL-4, IL-13 and IL-10, which are inhibitory (Jimi et al., 1998; Datta et al., 2008). Hence, cytokines have been shown to be important regulators of osteoclast activity in mice and might therefore influence calcium homeostasis in cattle. Among the proinflammatory cytokines that are believed to have osteoclastogenic effects (Datta et al., 2008), in our study chemokine (CXC-motif) ligand 10 expression was higher in heifers 
before calving, IL-1 $\beta$ was highly significantly higher at the time of calving in heifers and, although its receptor antagonist IL-1RA followed a similar pattern, it did not differ significantly between cows and heifers. However, TNF- $\alpha$ and IL-6 values were similar in heifers and cows at all time points. Interferon- $\gamma$ has been shown to suppress osteoclasts (Datta et al., 2008), and its mRNA expression was higher in cows postpartum but was not different on the day of calving. Interleukin 10, also known to inhibit osteoclast activity (Datta et al., 2008), did not differ between heifers and cows at any time point in our study.

Interleukin-2 and IL-2 receptor $\alpha$ are involved in the stimulation of T-cell immunologic memory, being necessary for the proliferation and activation of specific cytotoxic T cells. Higher levels of gene expression of IL 2 in the postpartum pluriparous cow might be suggestive of greater probability of exposure to more foreign fetal antigens during late gestation and the parturient periods in cows compared with heifers. The data showed a possible relationship between IL 2 expression and the number of lactations (Figure 3), in which the variability in cows was greater than in heifers.

Alkaline phosphatase, a membrane-bound enzyme with several isoforms, is an important marker of bone formation (Allen, 2003). In the present study we did not attempt to differentiate the bone-specific isoenzyme from other isoforms, such as liver-specific ALP. Nonetheless, activity was consistently higher in heifers than in cows, which likely reflects the effects of age and growth. Recent work has shown that bonespecific ALP decreases in cattle with increasing parity (Mohebbi et al., 2010), decreasing more or less linearly from $45.1 \mathrm{U} / \mathrm{L}$ in the first lactation to $15.2 \mathrm{U} / \mathrm{L}$ in the fifth lactation. Previous studies did not find any differences in plasma ALP activities in dry cows, normal postparturient cows, or cows with parturient paresis (Littledike et al., 1970; Lappeteläinen et al., 1993), so ALP concentrations in plasma should not be considered to be a measure of the susceptibility of those animals to parturient hypocalcaemia.

\section{CONCLUSIONS}

This study demonstrated several significant differences between the immune phenotypes of apparently normal heifers and cows, which warrant further investigation. The overall pattern of cytokine gene expression and immune cell profiles was different in the 2 age groups, with higher variability between time points in heifers than in cows.

\section{ACKNOWLEDGMENTS}

The authors acknowledge and thank Rod Verrall, Andres Ardila, and Caroline Allardyce of The University of Queensland for assistance with sample collection, and staff from the Animal Genetics Laboratory in the School of Veterinary Science for technical assistance with laboratory procedures. We also thank David Lappin from the University of Glasgow (UK) for critically reading the manuscript, and Toby St George for his initial idea that milk fever might have an immunemediated etiology and for his probing and helpful suggestions.

\section{REFERENCES}

Allen, M. J. 2003. Biochemical markers of bone metabolism in animals: uses and limitations. Vet. Clin. Pathol. 32:101-113.

Ametaj, B. N., J. P. Goff, R. L. Horst, B. J. Bradford, and D. C. Beitz. 2003. Presence of acute phase response in normal and milk fever dairy cows around parturition. Acta Vet. Scand. 98:241.

Boyce, B. F., and L. Xing. 2008. Functions of RANKL/RANK/OPG in bone modelling and remodelling. Arch. Biochem. Biophys. 473:139-146.

Coussens, P. M., N. Verman, M. A. Coussens, M. D. Elftman, and A. M. McNulty. 2004. Cytokine gene expression in peripheral blood mononuclear cells and tissues of cattle infected with Mycobacterium avium ssp. paratuberculosis: Evidence for an inherent proinflammatory gene expression pattern. Infect. Immun. 72:1409-1422.

Datta, H. K., W. F. Ng, J. A. Walker, S. P. Tuck, and S. S. Varanasi. 2008. The cell biology of bone metabolism. J. Clin. Pathol. 61:577-587.

Davies, C. J., J. R. Hill, J. L. Edwards, F. N. Schrick, P. J. Fisher, J. A. Eldridge, and D. H. Schlafer. 2004. Major Histocompatibility antigen expression on the bovine placenta: Its relationship to abnormal pregnancies and retained placenta. Anim. Reprod. Sci. 82-83:267-280.

Goff, J. P., and R. L. Horst. 1997. Physiological changes at parturition and their relationship to metabolic disorders. J. Dairy Sci. 80:1260-1268.

Gray, C. P., T. D. St George, and N. N. Jonsson. 2007. Milk fever in dairy cattle: A novel hypothesis for an immune mediated aetiology. Cattle Pract. 15:277-282.

Ingvartsen, K. L., R. J. Dewhurst, and N. C. Friggens. 2003. On the relationship between lactational performance and health: Is it yield or metabolic imbalance that cause production diseases in dairy cattle? A position paper. Livest. Prod. Sci. 83:277-308.

Jimi, E., I. Nakamura, T. Ikebe, S. Akiyama, N. Takahashi, and T. Suda. 1998. Activation of NF- $\kappa \mathrm{B}$ is involved in the survival of osteoclasts promoted by interleukin-1. J. Biol. Chem. 273:87998805.

Karcher, E. L., D. C. Beitz, and J. R. Stabel. 2008. Modulation of cytokine gene expression and secretion during the periparturient period in dairy cows naturally infected with Mycobacterium avium ssp. paratuberculosis. Vet. Immunol. Immunopathol. 123:277-288.

Lappeteläinen, R., E. Lappeteläinen, T. Hassinen, M. Hahl, A. Piskanen, and P. H. Mäenpää. 1993. Biochemical indicators of bone metabolic activity in bovine periparturient hypocalcaemia. J. Vet. Med. A 40:67-72.

Leibbrandt, A., and J. M. Penninger. 2008. RANK/RANKL: Regulators of immune responses and bone physiology. Ann. N. Y. Acad. Sci. 1143:123-150.

Littledike, E. T., S. C. Whipp, D. A. Witzel, and A. L. Baetz. 1970. Insulin, corticoids and parturient paresis. Pages 165-176 in Parturient Paresis. J. J. B. Anderson, ed. Academic Press, New York, NY. 
Maret, A., J. D. Coudert, L. Garidou, G. Foucras, P. Gourdy, A. Krust, S. Dupont, P. Chambon, P. Druet, F. Bayard, and J. C. Guery. 2003. Estradiol enhances primary antigen-specific CD4 T cell responses and Th1 development in vivo. Essential role of estrogen receptor alpha expression in hematopoietic cells. Eur. J. Immunol. 33:512-521.

Miyaura, H., and M. Iwata. 2002. Direct and indirect inhibition of Th1 development by progesterone and glucocorticoids. J. Immunol. 168:1087-1094.

Mohebbi, A., A. Khaghami, and A. Mohammadnia. 2010. Bone-specific alkaline phosphatase activity in dairy cows. Comp. Clin. Pathol. 19:33-36.

Mulligan, F. J., and M. L. Doherty. 2008. Production diseases of the transition cow. Vet. J. 176:3-9.

Preisler, M. T., P. S. Weber, R. J. Pempelmann, R. J. Erskine, H. Hunt, and J. L. Burton. 2000. Glucocorticoid receptor downregulation in neutrophils of periparturient cows. Am. J. Vet. Res. $61: 14-19$
Radcliff, R. P., B. L. McCormack, B. A. Crooker, and M. C. Lucy 2003. Growth hormone (GH) binding and expression of GH receptor $1 \mathrm{~A}$ mRNA in hepatic tissue of periparturient dairy cows. J. Dairy Sci. 86:3933-3940.

Singh, J., R. D. Murray, G. Mshelia, and Z. Woldehiwet. 2008. The immune status of the bovine uterus during the peripartum period. Vet. J. 175:301-309.

Strandberg, Y., C. Gray, T. Vuocolo, L. Donaldson, M. Broadway, and R. Tellam. 2005. Lipopolysaccharide and lipoteichoic acid induce different innate immune responses in bovine mammary epithelial cells. Cytokine 31:72-86.

van Engelen, E., M. W. de Groot, V. N. A. Breeveld-Dwarkasing, M. E. Everts, G. C. van der Weyden, M. A. M. Taverne, and V. P. M. G. Rutten. 2009. Cervical ripening and parturition in cows are driven by a cascade of pro-inflammatory cytokines. Reprod. Domest. Anim. 44:834-841. 